\title{
Characterization of gas phase aggregates of bis(2-ethylhexyl)sulfosuccinate (AOT) and divalent metal ions. Elimination of radical species in the decomposition pathways of even-electron [AOTM" $\left.{ }^{\prime \prime} \mathrm{Cl}_{2}\right]^{-}$anions
}

\author{
Gianluca Giorgi, $^{a *}$ Leopoldo Ceraulo $^{\mathrm{b}, \mathrm{c}}$ and Vincenzo Turco Liveri ${ }^{\mathrm{d}}$
}

\begin{abstract}
Structure and properties of even-electron anionic species formed by bis(2-ethylhexyl)sulfosuccinate (AOT) and divalent metal ions $\left(\mathrm{M}^{\prime \prime}\right)$ with stoichiometry $\left[\mathrm{AOTM} \mathrm{C}^{\prime \prime} \mathrm{Cl}_{2}\right]^{-}$have been investigated by using electrospray ionization and different mass spectrometry techniques, such as high resolution, accurate mass measurements, collision-induced dissociation (CID) multiple-stage mass spectrometry. Owing to CID, eliminations of neutrals, mainly consisting in hydrochloric acid, 2-ethyl-1-hexene and 2-ethylhexanol, and an unexpected loss of an alkyl radical have been observed. The radical anions $\left[\mathrm{C}_{4} \mathrm{HO}_{6} \mathrm{SM}^{\prime \prime} \mathrm{Cl}\right]^{-\bullet}$ so produced have been characterized by $\mathrm{MS}^{3}$ experiments. Density functional theory calculations have been carried out for investigating structure and stability of the ionic species formed in the decomposition pathways. Copyright $\odot 2012$ John Wiley \& Sons, Ltd.
\end{abstract}

Keywords: surfactants; electrospray; even electron rule; tandem mass spectrometry; theoretical calculations

\section{Introduction}

Surfactant aggregation depends upon various factors such as conformational dynamics, presence and nature of hydrophobic and hydrophilic moieties, anisotropic surfactant-surfactant noncovalent interactions, and so on. ${ }^{[1,2]}$ Surfactant molecular properties also play a key role on the capability of entrapping in their interior host species, such as water molecules, metal ions, ${ }^{[3,4]}$ so that their solubility, reactivity and/or physical properties in the system are modified. The solubilization of inorganic salts in solutions of reverse micelles produces interesting specialized media as lubricants. ${ }^{[5]}$ Technological and biomedical applications of aggregates might involve their use as nanocarriers of drugs or biomolecules, mass and energy carriers in the atmosphere, atmospheric cleaning agents, and nanoreactors for specialized chemical reactions in a confined space.

Investigation on surfactant aggregation in liquid, liquid crystalline, and solid phases has produced a vast literature, but only a few investigations concerning surfactant self-assembling in the gas phase has been carried out. Indeed, the gas phase offers remarkable theoretical and practical information on surfactant-surfactant forces, on the ability to incorporate selected neutral or charged species, on the charge state effects, and so on. ${ }^{[6]}$ All this is determined as intrinsic properties, without the influence of surfactant-solvent interactions and of reticular or packing forces.

Sodium bis(2-ethylhexyl)sulfosuccinate (AOTNa, Scheme 1), an extensively used surfactant, ${ }^{[7-17]}$ can interact with a wide class of guest molecules to form species with different degree of aggregation that find applications in several fields, such as nanoreactors ${ }^{[18,19]}$ and nanomaterial science. ${ }^{[20]}$
Recently, we have shown that AOTNa can interact with alkaline, ${ }^{[21,22]}$ and divalent metal ions ${ }^{[23]}$ forming gas phase reverse micelle-like aggregates that have been characterized by mass spectrometry and theoretical calculations. A study on multiple charged gas phase AOTNa reverse micelles and their encapsulation of glycine has been recently reported in the literature. ${ }^{[24]}$

In the frame of our research project aimed at investigating gas phase properties of surfactants and their interactions, ${ }^{[25,26]}$ we wish to report here on the gas phase characterization and collisioninduced dissociation (CID) of negatively charged $\left[\mathrm{AOTM} \mathrm{MCl}_{2}\right]^{-}$ monomers produced by electrospray ionization. Under the low-energy CID regime, in addition to losses of 2-ethyl-1-hexene, 2-ethylhexanol and hydrochloric acid, unexpected eliminations of radical species from the AOT alkyl chain were observed in $M^{2}$ and confirmed by $\mathrm{MS}^{\mathrm{n}}$ experiments and high resolution accurate mass measurements. Structure and stability of different species formed in the decomposition pathways have been investigated by density functional theory calculations.

* Correspondence to: Gianluca Giorgi, University of Siena, Department of Chemistry, via Aldo Moro, 1-53100 Siena, Italy.E-mail: gianluca.giorgi@unisi.it

a Dipartimento di Chimica, Università degli Studi di Siena, Via Aldo Moro I-53100 Siena, Italy

b Dipartimento di Scienze e Tecnologie Molecolari e Biomolecolari, Università degli Studi di Palermo, Via Archirafi, 32 I-90123 Palermo, Italy

c UniNetLab, Università degli Studi di Palermo, Via Marini, 14 I-90100 Palermo, Italy

d Dipartimento di Chimica "Stanislao Cannizzaro", Università degli Studi di Palermo, Viale delle Scienze I-90128 Palermo, Italy 
<smiles>CCCCC(CC)COC(=O)CC(C(=O)OCC(CC)CCCC)[S@@]([NH])([O])O</smiles>

Scheme 1. Chemical structure of bis(2-ethylhexyl)sulfosuccinate (AOT) sodium salt.

\section{Experimental}

\section{Materials}

Sodium bis(2-ethylhexyl)sulfosuccinate (99\%) and chloride salts of magnesium, calcium, manganese, and nickel were purchased from Sigma-Aldrich-Fluka (Milan, Italy).

\section{Mass spectrometry}

Electrospray measurements have been carried out on a LCQDECA ion trap and on a LTQ-XP-Orbitrap instrument (Thermo, Bremen, D). Operating conditions of the ESI source were as follows: spray voltage $-4.5 \mathrm{kV}$; capillary temperature $200^{\circ} \mathrm{C}$; sheath gas (nitrogen) flow rate ca. $0.75 \mathrm{~L} / \mathrm{min}$.

$M^{n}{ }^{n}$ product ion experiments were carried out inside the ion trap by isolating the precursor ion by broadband ejection of the accompanying ions and then by applying CID; collision gas: He; collision energy: $1-5 \mathrm{eV}$ (laboratory frame). The mass window was $2 \mathrm{u}$. High resolution measurements were carried out by using an Orbitrap analyzer operating in the mass resolution range $30 \quad 000-100000$ and calibrated using the manufacturer's calibration mixture. Mass accuracies $<2$ p.p.m. were obtained before and after each series of experiments. About 30-50 scans were recorded and averaged for accurate mass measurements.

Energy-resolved mass spectrometry data have been obtained by varying the collision energy $(1 \div 3 \mathrm{eV})$ in $\mathrm{MS} / \mathrm{MS}$ experiments.

Solutions of $1: 1$ AOTNa : metal salt in water/methanol $\left(1 \times 10^{-4} \mathrm{M}, 50: 50 \mathrm{v} / \mathrm{v}\right)$ were introduced via direct infusion at a flow rate of $5 \mu \mathrm{L} / \mathrm{min}$.

\section{Theoretical calculations}

Density functional theory calculations were performed on some relevant ionic structures by using Gaussian $09^{[27]}$ implemented on an IBM P575 Power 6 supercomputer at Cineca in Bologna (Italy). All geometries were fully optimized without any constraints using the Becke 3 LYP $(B 3 L Y P)^{[28]}$ method with the $6-311+G(d, p)$ basis set. The final lowest energy geometries were confirmed as minima on the potential energy surface by normal-mode vibrational frequency calculations that produced all real frequencies. Zero-point energies and statistical thermodynamic properties at $298.15 \mathrm{~K}$ and $1 \mathrm{~atm}$ were also calculated.
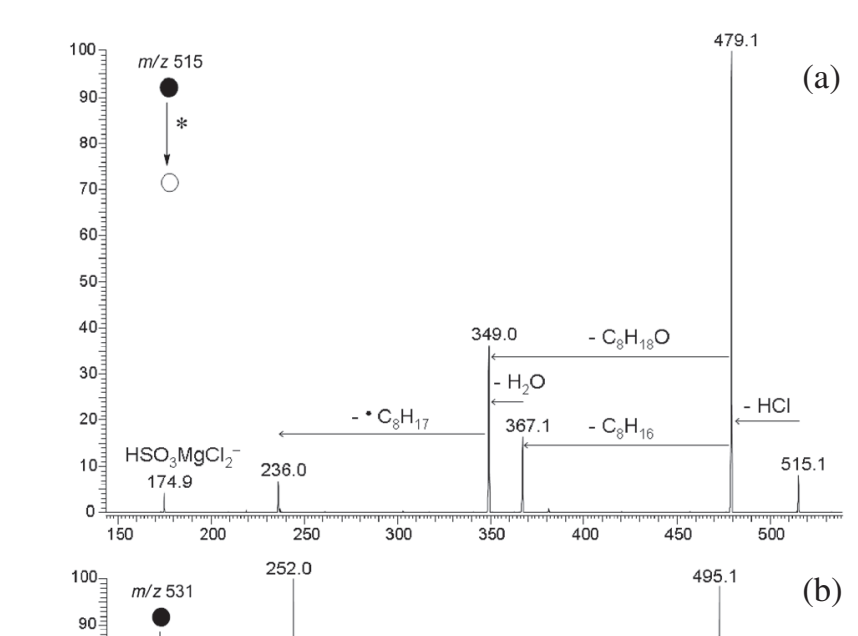

(b)
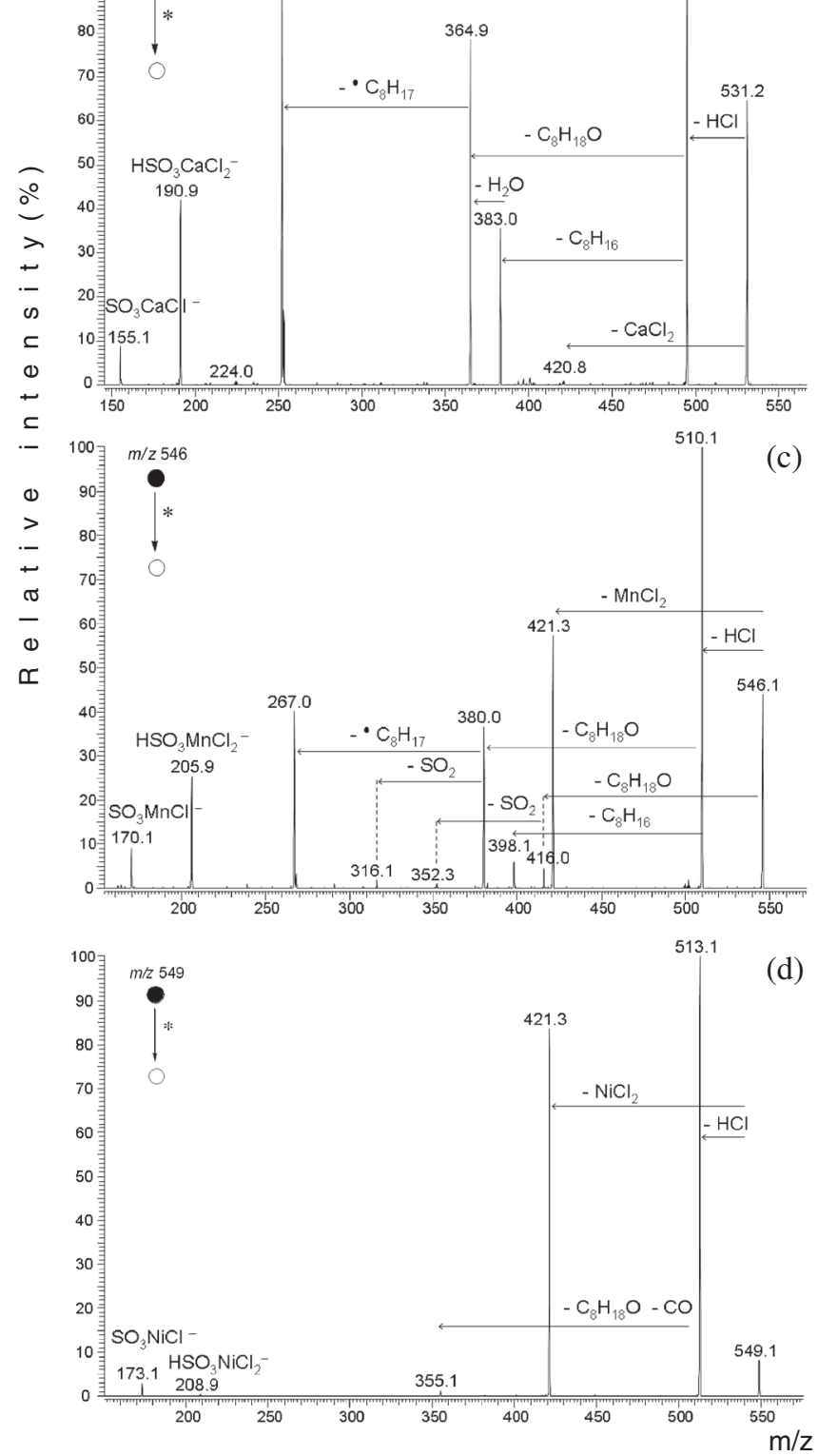

Figure 1. ESI(-) low-energy collision MS/MS spectra obtained by selecting $\left[\mathrm{AOTM}^{\mathrm{N}} \mathrm{Cl}_{2}\right]^{-}$as precursor ion $\left(E_{\text {coll }}=1.65 \mathrm{eV}\right) . \mathrm{M}^{\prime \prime}=\mathrm{Mg}(\mathrm{a}), \mathrm{Ca}(\mathrm{b}), \mathrm{Mn}(\mathrm{c})$, and $\mathrm{Ni}(\mathrm{d})$. 
Table 1. MS/MS accurate mass measurements data obtained by selecting the species $\left[\mathrm{AOTMnCl}_{2}\right]^{-}$as precursor ions

\begin{tabular}{|c|c|c|c|c|}
\hline Measured $m / z$ & Formula & $\mathrm{RDB}^{\mathrm{a}}$ & Error (ppm) & Attribution \\
\hline 546.1027 & $\mathrm{C}_{20} \mathrm{H}_{37} \mathrm{O}_{7} \mathrm{SMnCl}_{2}$ & 1.5 & 0.76 & {$[\mathrm{AOTMnCl}]^{-}(\mathrm{M})$} \\
\hline 510.1222 & $\mathrm{C}_{20} \mathrm{H}_{36} \mathrm{O}_{7} \mathrm{SMnCl}$ & 2.5 & 0.46 & {$[\mathrm{M}-\mathrm{HCl}]^{-}$} \\
\hline 421.2269 & $\mathrm{C}_{20} \mathrm{H}_{37} \mathrm{O}_{7} \mathrm{~S}$ & 2.5 & 0.84 & {$\left[\mathrm{M}-\mathrm{MnCl}_{2}\right]^{-}$} \\
\hline 415.9672 & $\mathrm{C}_{12} \mathrm{H}_{19} \mathrm{O}_{6} \mathrm{SMnCl}_{2}$ & 2.5 & 1.69 & {$\left[\mathrm{M}-\mathrm{C}_{8} \mathrm{H}_{18} \mathrm{O}\right]^{-}$} \\
\hline 398.0007 & $\mathrm{C}_{12} \mathrm{H}_{20} \mathrm{O}_{7} \mathrm{SMnCl}$ & 2.5 & 0.69 & {$\left[(\mathrm{M}-\mathrm{HCl})-\mathrm{C}_{8} \mathrm{H}_{16}\right]^{-}$} \\
\hline 382.0057 & $\mathrm{C}_{12} \mathrm{H}_{20} \mathrm{O}_{6} \mathrm{SMnCl}$ & 2.5 & 0.55 & {$\left[(\mathrm{M}-\mathrm{HCl})-\mathrm{C}_{8} \mathrm{H}_{16} \mathrm{O}\right]^{-}$} \\
\hline 379.9902 & $\mathrm{C}_{12} \mathrm{H}_{18} \mathrm{O}_{6} \mathrm{SMnCl}$ & 3.5 & 0.87 & {$\left[(\mathrm{M}-\mathrm{HCl})-\mathrm{C}_{8} \mathrm{H}_{18} \mathrm{O}\right]^{-}$} \\
\hline 352.0042 & $\mathrm{C}_{12} \mathrm{H}_{19} \mathrm{O}_{4} \mathrm{MnCl}_{2}$ & 2.5 & -1.36 & {$\left[\mathrm{M}-\mathrm{C}_{8} \mathrm{H}_{18} \mathrm{O}-\mathrm{SO}_{2}\right]^{-}$} \\
\hline 316.0284 & $\mathrm{C}_{12} \mathrm{H}_{18} \mathrm{O}_{4} \mathrm{MnCl}$ & 3.5 & 1.36 & {$\left[(\mathrm{M}-\mathrm{HCl})-\mathrm{C}_{8} \mathrm{H}_{18} \mathrm{O}-\mathrm{SO}_{2}\right]^{-}$} \\
\hline 291.0913 & $\mathrm{C}_{12} \mathrm{H}_{19} \mathrm{O}_{6} \mathrm{~S}$ & 3.5 & 1.71 & {$\left[\left(\mathrm{M}-\mathrm{MnCl}_{2}\right)-\mathrm{C}_{8} \mathrm{H}_{18} \mathrm{O}\right]^{-}$} \\
\hline 267.8648 & $\mathrm{C}_{4} \mathrm{H}_{2} \mathrm{O}_{6} \mathrm{SMnCl}$ & 3.5 & 0.45 & {$\left[(\mathrm{M}-\mathrm{HCl})-\mathrm{C}_{8} \mathrm{H}_{18} \mathrm{O}-\mathrm{C}_{8} \mathrm{H}_{16}\right]^{-}$} \\
\hline 266.8570 & $\mathrm{C}_{4} \mathrm{HO}_{6} \mathrm{SMnCl}$ & 4.0 & 0.66 & $\left.[(\mathrm{M}-\mathrm{HCl}))-\mathrm{C}_{8} \mathrm{H}_{18} \mathrm{O}-\mathrm{C}_{8} \mathrm{H}_{17}\right]^{-}$ \\
\hline 254.0047 & $\mathrm{C}_{8} \mathrm{H}_{17} \mathrm{OMnCl}_{2}$ & -0.5 & 1.88 & {$\left[\mathrm{C}_{8} \mathrm{H}_{17} \mathrm{OMnCl}_{2}\right]^{-}$} \\
\hline 238.8624 & $\mathrm{C}_{3} \mathrm{HO}_{5} \mathrm{SMnCl}$ & 3.0 & 1.84 & {$\left[\mathrm{C}_{3} \mathrm{HO}_{2} \mathrm{SO}_{3} \mathrm{MnCl}^{-\bullet}\right.$} \\
\hline 227.1290 & $\mathrm{C}_{12} \mathrm{H}_{19} \mathrm{O}_{4}$ & 3.5 & 0.47 & {$\left[(\mathrm{M}-\mathrm{HCl})-\mathrm{C}_{8} \mathrm{H}_{16}-\mathrm{HSO}_{3} \mathrm{MnCl}\right]^{-}$} \\
\hline 205.8413 & $\mathrm{HSO}_{3} \mathrm{MnCl}_{2}$ & -0.5 & 1.98 & {$\left[\mathrm{HSO}_{3} \mathrm{MnCl}_{2}\right]^{-}$} \\
\hline 169.8646 & $\mathrm{SO}_{3} \mathrm{MnCl}$ & 0.5 & 1.97 & {$\left[\mathrm{HSO}_{3} \mathrm{MnCl}_{2}-\mathrm{HCl}\right]^{-}$} \\
\hline
\end{tabular}

${ }^{\mathrm{a}}$ Ring and double-bond equivalents (RDB). An integer with a remainder of 0.5 indicates an even-electron ion, whereas an exact integer indicates an odd-electron ion.

\section{Results and discussion}

\section{Mass spectrometry and $M S^{n}$ experiments}

By mixing AOTNa and $\mathrm{M}^{\prime \prime} \mathrm{Cl}_{2}\left(\mathrm{M}^{\mathrm{I}}=\mathrm{Mg}, \mathrm{Ca}, \mathrm{Mn}, \mathrm{Ni}\right)$ (molar ratio $1: 1$ ) in water/methanol $\left(1 \times 10^{-4} \mathrm{M}, 50: 50 \mathrm{v} / \mathrm{v}\right)$ and electrospraying the resulting solution in negative ion mode, various anionic species are formed. The simplest ones containing a divalent cation are the monomers $\left[\mathrm{AOTM}^{\| \prime} \mathrm{Cl}_{2}\right]^{-}$that have been characterized by low and high resolution mass spectrometry, CID MS ${ }^{n}$ experiments, energy-resolved mass spectrometry and theoretical calculations. Their $\mathrm{MS}^{2}$ product ion spectra are reported in Fig. 1, whereas accurate mass data relevant to $[\mathrm{AOTMnCl}]^{-}$and its product ions are given in Table 1.

Owing to low-energy CIDs, both common decomposition pathways and specific ones, depending upon the nature of the metal ion, occur (Fig. 1). A common decomposition is the loss of $\mathrm{HCl}$ yielding the most abundant product ions for all the complexes investigated. This suggests that there are interactions between chlorides and hydrogen atoms of the AOT, so to allow elimination of $\mathrm{HCl}$.

When the monomer $\left[\mathrm{AOTM}^{\mathrm{II}} \mathrm{Cl}_{2}\right]^{-}$contains $\mathrm{Mn}^{\mathrm{II}}$ or $\mathrm{Ni}^{\mathrm{II}}$, the direct elimination of $\mathrm{M}^{\mathrm{Il}} \mathrm{Cl}_{2}$ is observed, yielding very abundant AOT product ions (Fig. 1). This pathway also occurs when calcium is the metal ion, but the resulting product ions have relative abundances around $1 \%$. This behavior suggests that both manganese and nickel interact more weakly with the sulfonate moiety in comparison with magnesium and calcium, and/or that $\mathrm{M}^{\mathrm{II}} \mathrm{Cl}_{2}\left(\mathrm{M}^{\mathrm{II}}=\mathrm{Mn}, \mathrm{Ni}\right)$ is particularly stable.

Other common ions originating from direct decomposition of [AOTM" $\left.\mathrm{Cl}_{2}\right]^{-}$are due to $\left[\mathrm{HSO}_{3} \mathrm{M}^{\mathrm{II}} \mathrm{Cl}_{2}\right]^{-}$that, on turn, can lose $\mathrm{HCl}$ yielding $\left[\mathrm{SO}_{3} \mathrm{M}^{\mathrm{II}} \mathrm{Cl}\right]^{-}$(Fig. 1), whose compositions have been determined by accurate mass measurements (Table 1).

Other abundant ions observed in the MS/MS spectra of the monomers $\left[\mathrm{AOTM}^{\mathrm{II}} \mathrm{Cl}_{2}\right]^{-}$are the result of consecutive decomposition reactions whose kinetics is faster than the trapping time and whose origin has been studied in detail by $\mathrm{MS}^{\mathrm{n}}$ experiments.
With the exception of $\left[\mathrm{AOTNi} \mathrm{Cl}_{2}\right]^{-}$, owing to low-energy CID, after loss of $\mathrm{HCl}$, two decomposition pathways are activated: one consists in the loss of 2-ethyl-1-hexene $\left(\mathrm{C}_{8} \mathrm{H}_{16}, 112 \mathrm{u}\right)$, whereas the other yields the elimination of 2-ethylhexanol $\left(\mathrm{C}_{8} \mathrm{H}_{18} \mathrm{O}, 130 \mathrm{u}\right)$ (Fig. 1).

The behavior of $\left[\mathrm{AOTNiCl}_{2}\right]^{-}$is quite different from the other [AOTM" $\left.\mathrm{Cl}_{2}\right]^{-}$species: eliminations of $\mathrm{C}_{8} \mathrm{H}_{16}$ and $\mathrm{C}_{8} \mathrm{H}_{18} \mathrm{O}$ are not detectable, and the only product ions, due to decomposition of the AOT alkyl chains, are at $\mathrm{m} / \mathrm{z} 355$ (rel. intensity 3\%), likely produced by consecutive eliminations of $\mathrm{HCl}, \mathrm{C}_{8} \mathrm{H}_{18} \mathrm{O}$ and $\mathrm{CO}_{2}$ [Fig. 1(d)].

Losses of $\mathrm{C}_{8} \mathrm{H}_{16}$ and $\mathrm{C}_{8} \mathrm{H}_{18} \mathrm{O}$ are quite common for AOT and characterize the gas phase decompositions of its cationic and anionic complexes formed with different metal ions. As an example, $\left[\mathrm{AOT}_{2} \mathrm{Li}_{3}\right]^{+}$and $\left[\mathrm{AOT}_{3} \mathrm{Li}_{4}\right]^{+}$decompose by eliminating $\mathrm{C}_{8} \mathrm{H}_{16}{ }^{[21]}$ while the dimeric anion $\left[\mathrm{AOT}_{2} \mathrm{~K}\right]^{-}$loses a $\mathrm{C}_{8} \mathrm{H}_{18} \mathrm{O}$ molecule followed by $\mathrm{C}_{8} \mathrm{H}_{16} \cdot{ }^{[22]}$ Regarding divalent metal ions, the cationic $\left[\mathrm{AOT}_{2} \mathrm{NaM}^{\prime \prime}\right]^{+}\left(\mathrm{M}^{\prime \prime}=\mathrm{Mg}, \mathrm{Ca}, \mathrm{Mn}, \mathrm{Ni}\right)$ species decompose by successive losses of 2-ethyl-1-hexene and water. ${ }^{[23]}$

Other decomposition pathways of $\left[\mathrm{AOTM}^{\mathrm{II}} \mathrm{Cl}_{2}\right]^{-}$involve eliminations of $\mathrm{SO}_{2}$ but they yield very low abundant ions (Fig. 1).

$\mathrm{MS}^{3}$ spectra obtained by selecting the species $\left[\mathrm{AOTM}^{\|} \mathrm{Cl}_{2}-\right.$ $\mathrm{HCl}^{-}\left(\mathrm{M}^{\mathrm{ll}}=\mathrm{Mg}, \mathrm{Ca}, \mathrm{Mn}\right)$ as precursor ions confirm eliminations of $\mathrm{C}_{8} \mathrm{H}_{16}$ and $\mathrm{C}_{8} \mathrm{H}_{18} \mathrm{O}$, already observed in the MS/MS spectra of [AOTM $\left.{ }^{\prime \prime} \mathrm{Cl}_{2}\right]^{-}$(Fig. 2 for $\mathrm{M}^{\mathrm{II}}=\mathrm{Mn}$ ). As $\mathrm{MS}^{3}$ spectra obtained by selecting the species [(AOTM $\left.\left.{ }^{\prime \prime} \mathrm{Cl}_{2}-\mathrm{HCl}\right)-\mathrm{C}_{8} \mathrm{H}_{16}\right]^{-}$show elimination of water, loss of $\mathrm{C}_{8} \mathrm{H}_{18} \mathrm{O}$ from [AOTM" $\left.\mathrm{Cl}_{2}-\mathrm{HCl}\right]^{-}$might be due to its direct elimination and/or to successive losses of $\mathrm{C}_{8} \mathrm{H}_{16}$ and $\mathrm{H}_{2} \mathrm{O}$. MS ${ }^{n}$ spectra obtained for species containing manganese are depicted in Fig. 2.

Further, main product ions present in the $\mathrm{MS}^{3}$ spectra of $\left[\mathrm{AOTM}^{\prime \prime} \mathrm{Cl}_{2}-\mathrm{HCl}^{-}\left(\mathrm{M}^{\prime \prime}=\mathrm{Mg}, \mathrm{Ca}, \mathrm{Mn}\right)\right.$ are due to $\left[\mathrm{C}_{4} \mathrm{HO}_{6} \mathrm{SM}^{\prime \prime} \mathrm{Cl}\right]^{-\cdot}$ formed by loss of $113 \mathrm{u}$ from [(AOTM" $\left.\left.\mathrm{Cl}_{2}-\mathrm{HCl}\right)-\mathrm{C}_{8} \mathrm{H}_{18} \mathrm{O}\right]^{-}$whose origin has been confirmed by $\mathrm{MS}^{4}$ measurements.

Elimination of $113 \mathrm{u}$ is an unexpected loss and, as the initial anions do not contain nitrogen atoms, it must be due to a radical 


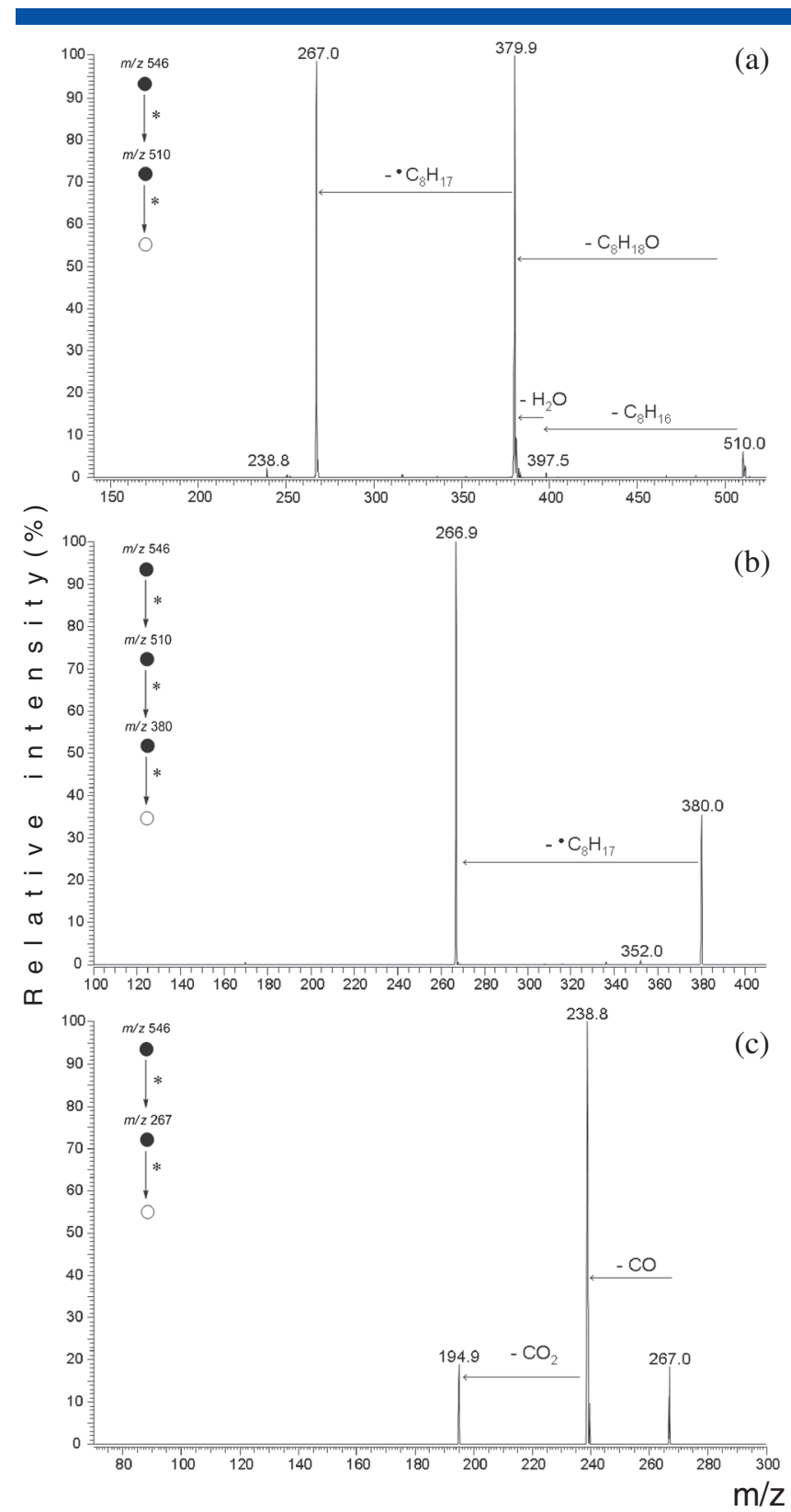

Figure 2. ESI(-) low-energy collision $\mathrm{MS}^{\mathrm{n}}$ spectra obtained by selecting ionic species formed by $\left[\mathrm{AOTMnCl}_{2}\right]^{-}$. (a) $\mathrm{MS}^{3}$ spectrum, precursor ion $\left[\mathrm{AOTMnCl}{ }_{2}-\mathrm{HCl}^{-}\right.$; (b) $\mathrm{MS}^{4}$ spectrum, precursor ion [(AOTMnCl $2-$ $\left.\mathrm{HCl})-\mathrm{C}_{8} \mathrm{H}_{18} \mathrm{O}\right]^{-}$; (c) $\mathrm{MS}^{3}$ spectrum, precursor ion [(AOTMnCl $\left.2-\mathrm{HCl}\right)-$ $\left.\mathrm{C}_{8} \mathrm{H}_{18} \mathrm{O}-{ }^{\cdot} \mathrm{C}_{8} \mathrm{H}_{17}\right]^{\cdot}$.

species. And indeed, accurate mass measurements show that the radical ${ }^{\circ} \mathrm{C}_{8} \mathrm{H}_{17}(113 \mathrm{u})$ is lost in this decomposition. Loss of radicals is a quite unusual reaction from even-electron species being an exception to the 'even-electron rule'. ${ }^{[29]}$ Further, none of the studies carried out on AOT and its aggregates reported in the literature have shown loss of radical species. ${ }^{[21-23]}$ In particular, negatively charged aggregates containing alkali metal ions do not decompose by loss of radical species. In fact, monomeric and dimeric anions with stoichiometry $\left[\mathrm{AOTM}^{\prime} \mathrm{X}\right]^{-}$and $\left[\mathrm{AOT}_{2} \mathrm{M}^{\prime}\right]^{-}\left(\mathrm{M}^{\prime}=\mathrm{Li}, \mathrm{Na}, \mathrm{K}, \mathrm{Cs}, \mathrm{Rb}\right)$ show losses of AOTM', $\mathrm{C}_{8} \mathrm{H}_{18} \mathrm{O}$, and $\mathrm{C}_{8} \mathrm{H}_{16}$ molecules. ${ }^{\text {[22] }}$

The formation of $\left[\mathrm{C}_{4} \mathrm{HO}_{6} \mathrm{SM}^{\mathrm{II}} \mathrm{Cl}\right]^{-*}$ is particularly favored in the case of $\left[\mathrm{AOTCaCl}_{2}\right]^{-}$. For collision energy $\left(E_{\text {coll }}\right)$ values higher than $1.7 \mathrm{eV}$, the $\left[\mathrm{C}_{4} \mathrm{HO}_{6} \mathrm{SCaCl}\right]^{-\bullet}$ radical anions $(\mathrm{m} / \mathrm{z}$ 365) become the most abundant species, whereas the anions $\left[\mathrm{AOTCaCl}_{2}-\mathrm{HCl}^{-}\right.$, which have the highest abundances for all the other complexes, decompose to the final product ions at $\mathrm{m} / \mathrm{z} 365$.

Collision-induced decompositions of the radical anions $\left[\mathrm{C}_{4} \mathrm{HO}_{6} \mathrm{SM}^{\mathrm{II}} \mathrm{Cl}\right]^{-\bullet}$ consist in consecutive eliminations of $\mathrm{CO}$ and $\mathrm{CO}_{2}$, suggesting that the strongest interaction sites of the metal cation are the oxygen atoms of the sulfonate moiety and not those belonging to the carboxylic moieties [Fig. 2(c)]. Furthermore, as the CID spectra are similar for all the metal complexes, it is likely that the structure of the radical anions is the same, independently by the nature of the metal ion.

The decomposition pathways of the $\left[\mathrm{AOTM}^{\|} \mathrm{Cl}_{2}\right]^{-}$anions are depicted in Scheme 2.

\section{Energy-resolved mass spectrometry}

Aimed at determining the stability of negatively charged aggregates formed by AOT with divalent metal ions, energy-resolved mass spectrometry measurements have been carried out. By plotting the relative abundances of precursor and product ions as a function of the collision energy, the so called breakdown curves are obtained. They show that the collision energy required to dissociate the precursor ions $\left[\mathrm{AOTM}^{\mathrm{II}} \mathrm{Cl}_{2}\right]^{-}$to $50 \%$ of their intensity is $1.68,1.63,1.53$, and $1.42 \mathrm{eV}$ when $\mathrm{M}^{\mathrm{II}}=\mathrm{Ca}, \mathrm{Mn}, \mathrm{Mg}$, and $\mathrm{Ni}$, respectively (Fig. 3). Even if these values should be regarded as upper limits to the thermochemical thresholds, as they may be influenced by kinetic and competitive shifts and/ or reverse energy barriers, ${ }^{[30,31]}$ the energy values can be assumed as a trend of the stability of the different monomeric anions. The data show that with $\mathrm{M}^{\prime \prime}=\mathrm{Ca}$ and $\mathrm{Mg}$, the anions $\left[\text { AOTM }{ }^{\prime \prime} \mathrm{Cl}_{2}\right]^{-}$have the highest stability, whereas the lowest is observed for $\mathrm{M}^{\mathrm{I}}=\mathrm{Ni}$.

With collision energy up to $1.7 \mathrm{eV}$, the ions [AOTM" $\left.{ }^{\prime \prime} \mathrm{Cl}_{2}-\mathrm{HCI}\right]^{-}$ are the most abundant product ions formed owing to low-energy CID. The $50 \%$ of their abundance is reached for $E_{\text {coll }}$ equal to 1.33 , $1.40,1.56$, and $1.55 \mathrm{eV}$ for $\mathrm{M}^{\mathrm{II}}=\mathrm{Ni}, \mathrm{Mg}, \mathrm{Ca}, \mathrm{Mn}$, respectively.

Other important species formed in the gas phase decompositions of $\left[\mathrm{AOTM}^{\prime \prime} \mathrm{Cl}_{2}\right]^{-}$are the product ions $\left[\mathrm{AOTM}^{\prime \prime} \mathrm{Cl}_{2}-\mathrm{HCl}-\right.$ $\left.\mathrm{C}_{8} \mathrm{H}_{18} \mathrm{O}\right]^{-}$whose relative abundance remains below $50 \%$ when $M^{\prime \prime}=M g$ and $M n$ (Fig. 3). If $M^{\prime \prime}=C a$ their abundance is high (about $75 \%$ ) when $E_{\text {coll }}=1.7 \mathrm{eV}$ and decreases until $60 \%$ by increasing the collision energy because of their further decomposition to $\left[\mathrm{C}_{4} \mathrm{HO}_{6} \mathrm{SCaCl}\right]^{-*}$.

It has been already outlined that the formation of the radical anions is particularly favored when the divalent metal ion is calcium, and the species $\left[\mathrm{C}_{4} \mathrm{HO}_{6} \mathrm{SCaCl}\right]^{-\bullet}(\mathrm{m} / \mathrm{z}$ 365) constitute the most abundant ions for $E_{\text {coll }}$ higher than $1.7 \mathrm{eV}$ [Fig. 3(b)].

\section{Theoretical calculations}

Several structures of the anion $[\mathrm{AOTMgCl}]^{-}$, considered as a representative member of the species $\left[\mathrm{AOTM}^{\|} \mathrm{Cl}_{2}\right]^{-}$, have been submitted to energy calculations. They differ for the conformation and coordination sites of $\mathrm{AOT}^{-}$.

The two most stable structures $(\mathbf{1} \mathbf{a}, \mathbf{1 b})$ are depicted in Fig. 4 and their energy values are reported in Table 2 . In both structures, magnesium shows a tetrahedral coordination formed by the two chloride anions, one oxygen from the $\mathrm{SO}_{3}^{-}$moiety, and one carboxyl oxygen atom of the $\alpha$ (1) or the $\beta$ (1) b) alkyl chain. These coordination modes allow the formation of a six-membered (1a) or a seven-membered (1) chelated ring. The distances of $\mathrm{Mg}-\mathrm{Cl}$ and $\mathrm{Mg}-\mathrm{O}$ averaged 2.305 and $2.053 \AA$, respectively. 


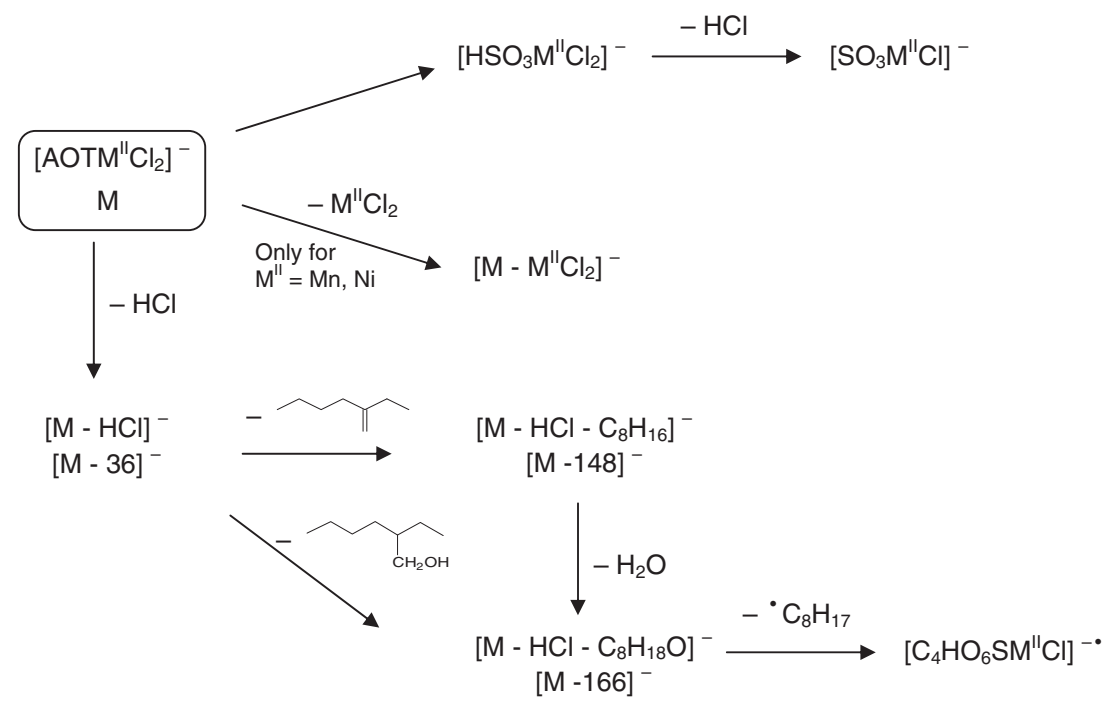

Scheme 2. Fragmentation pathways determined by $\mathrm{MS}^{\mathrm{n}}$ experiments for the monomeric anions $\left[\mathrm{AOTM} \mathrm{M}^{\prime \prime} \mathrm{Cl}_{2}\right]^{-}\left(\mathrm{M}^{\prime \prime}=\mathrm{Mg}, \mathrm{Ca}, \mathrm{Mn}, \mathrm{Ni}\right)$.

In the third structure (1c, Table 2) the metal ion shows a pyramidal coordination involving the two chloride ions, one oxygen from the $\mathrm{SO}_{3}^{-}$moiety, and one oxygen atom from each of the two carboxyl moieties.

In all the minimized structures, one chloride interacts with a hydrogen atom with distances of 2.954 and $2.978 \AA$ in $1 \mathbf{a}$ and $\mathbf{1 b}$, respectively. Although in $\mathbf{1 a}$ the interacting hydrogen belongs to the succinate moiety, in $\mathbf{1} \mathbf{b}$, the hydrogen belongs to the methyl group of the ethyl moiety in the $\alpha$ alkyl chain (Fig. 4). The existence of these interactions can well explain the elimination of $\mathrm{HCl}$ from $\left[\mathrm{AOTM}^{\mathrm{II}} \mathrm{Cl}_{2}\right]^{-}$as observed in $\mathrm{MS}^{\mathrm{n}}$ experiments.

Theoretical calculations have been also carried out on different $\left[\mathrm{AOTMgCl} \mathrm{HCl}_{2}^{-}\right.$structures obtained by $\mathbf{1 a}$ and $\mathbf{1} \mathbf{b}$ through the loss of $\mathrm{HCl}$. In the most stable (2a, Table 2, Fig. 5), produced by elimination of $\mathrm{HCl}$ from $\mathbf{1 a}$, the magnesium still maintains a tetrahedral coordination with one chloride and three oxygen atoms, one from the sulfonate moiety, and one from each of the carbonyl groups. As shown by $\mathrm{MS}^{\mathrm{n}}$ experiments, this species decomposes with loss of $\mathrm{C}_{8} \mathrm{H}_{18} \mathrm{O}$ that, in principle, might involve either the $\alpha$ or the $\beta$ alkyl chain. Examination of the bond lengths in $2 \mathbf{2 a}$ shows that the two $\mathrm{C}-\mathrm{O}$ single bonds are 1.329 and $1.385 \AA$ for the $\alpha$ and the $\beta$ alkyl chain, respectively, thus suggesting an easier fission of the $\mathrm{C}-\mathrm{O}$ bond linking the $\beta$ chain.

Structure $\mathbf{2} \mathbf{b}$ (Table 2 ) is obtained by eliminating $\mathbf{H C l}$ from $\mathbf{1} \mathbf{b}$. During the energy minimization process, the branched terminal $\mathrm{CH}_{2}$ group of the $\beta$ alkyl chain binds the carbon atom of the carboxyl group to form a tetrahydropyran ring. Also in this structure, the magnesium shows a tetrahedral coordination to one oxygen of each carboxyl group, one oxygen from the sulfonate moiety, and a chloride. The distance of $\mathrm{Mg}-\mathrm{O}$ averaged to $2.007 \AA$.

Structure $\mathbf{2 c}$ (Table 2) is analogous to $\mathbf{2 a}$, but the magnesium shows a coordination to two oxygen atoms of the sulfonate group, the methyne carbon atom, that has been produced by elimination of $\mathrm{HCl}$, and to a chloride.

Calculations have been also extended to the species [AOTMgCl $\left.2-\mathrm{HCl}-\mathrm{C}_{8} \mathrm{H}_{18} \mathrm{O}\right]^{-}$that are involved in the decomposition pathways of $[\mathrm{AOTMgCl}]^{-}$. It resulted that ionic structures produced by elimination of $\mathrm{C}_{8} \mathrm{H}_{18} \mathrm{O}$ from the $\alpha$ or $\beta$ alkyl chain of $\mathbf{2 a}$ have very close stability. Structure $\mathbf{3 a}$ (Table 2, Fig. 5) results owing to the loss of $\mathrm{C}_{8} \mathrm{H}_{18} \mathrm{O}$ from the $\beta$ alkyl chain. The metal ion maintains a tetrahedral coordination geometry interacting with an oxygen atom of the sulfonate group, one oxygen atom of the carboxyl, the carbon atom adjacent to that bearing the sulfonate group and a chloride.

The elimination of $\mathrm{C}_{8} \mathrm{H}_{18} \mathrm{O}$ from the $\alpha$ alkyl chain produces structure $\mathbf{3 b}$ (Table 2, Fig. 5) whose relative energy is $0.52 \mathrm{kcal}$ $\mathrm{mol}^{-1}$ higher than $\mathbf{3 a}$. In this structure, magnesium shows a trigonal planar coordination to an oxygen atom of the sulfonate group, one oxygen atom of the carboxyl, so to form a sevenmembered chelate ring and to a chloride. The two $\mathrm{Mg}-\mathrm{O}$ distances averaged to1.918 $\AA$.

Another structure is obtained by the elimination of the $\beta$ alkyl chain; $\mathbf{3 c}$ is $11.54 \mathrm{kcal} \mathrm{mol}^{-1}$ less stable than $\mathbf{3 a}$ (Table 2). In 3c, magnesium shows a tetrahedral coordination to an oxygen atom of the sulfonate group, one oxygen atom from a carboxyl moiety, one oxygen atom from the carbonyl and to a chloride.

A successive elimination of ${ }^{\circ} \mathrm{C}_{8} \mathrm{H}_{17}$ from the species 3 yields the radical $\left[\mathrm{C}_{4} \mathrm{HO}_{6} \mathrm{SMgCl}^{-}\right.$for which different possible structures have been submitted to theoretical calculations. The most stable (4a, Table 2, Fig. 5) has a dihydrofuran dione sulfonic acid structure in which the magnesium shows a tetrahedral coordination to two oxygen atoms of the sulfonate moiety, one oxygen of the carboxyl group and a chloride. The highest negative charge $(-0.66)$ is located on the carbon atom bearing the sulfonate moiety, whereas the spin density is almost delocalized over carbon and oxygen atoms. The highest value $(0.35)$ is shown by the methyne carbon atom.

The second most stable structure, $\mathbf{4 b}$ (Table 2), is a acyclic derivative of $\mathbf{4 a}$ in which the hydrogen atom is bound to the carbon atom bearing the sulfonate group, and magnesium has the same coordination mode.

\section{Conclusions}

This work has shown that divalent metal ions can interact with AOT forming anionic aggregates in the gas phase. The 

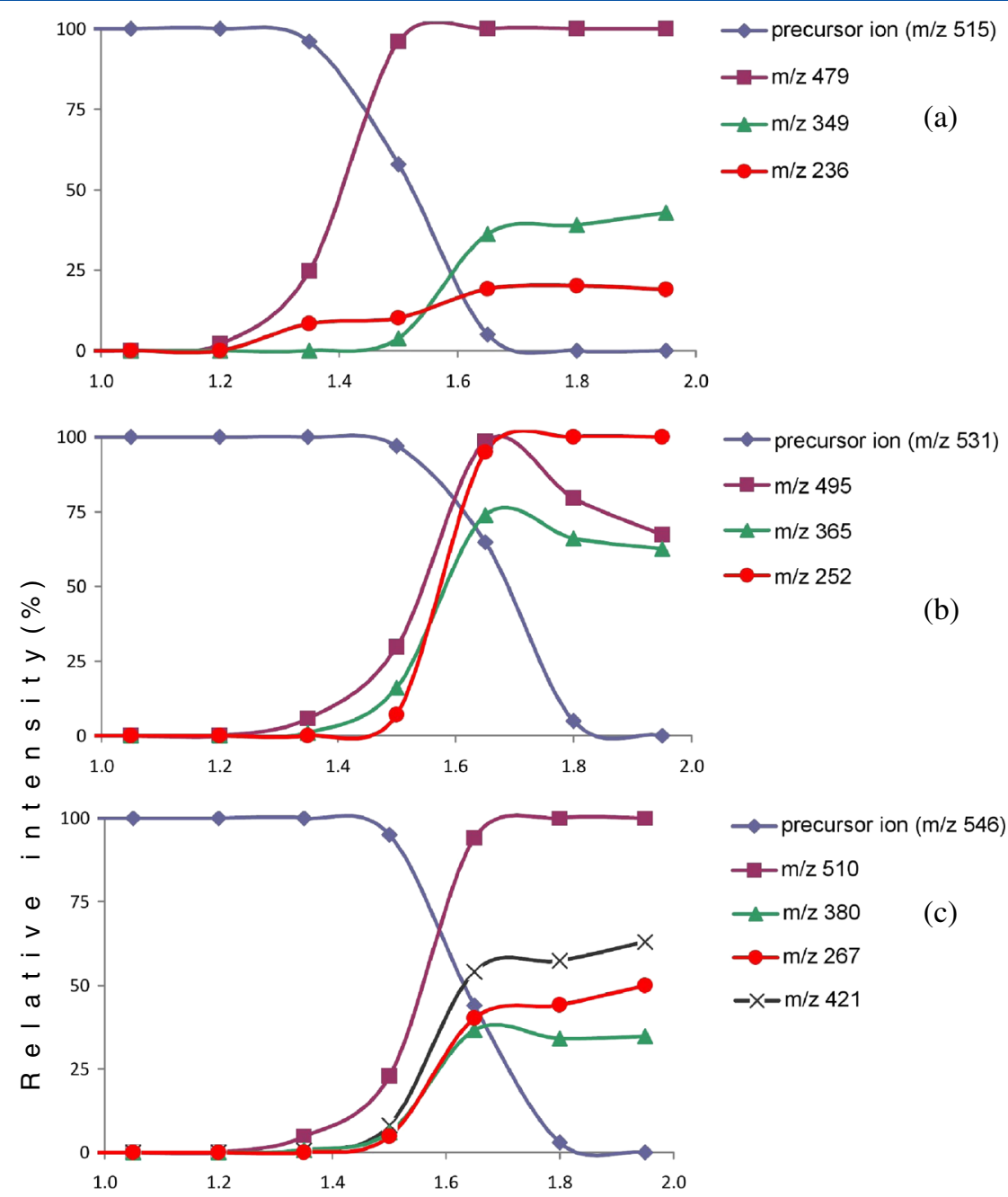

(b)

(a)

$-\mathrm{m} / \mathrm{z} 349$

$-m / 2236$
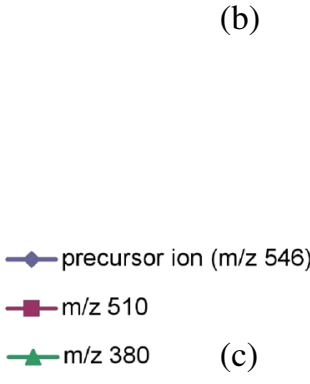

$\rightarrow-m / z 267$

$-x-m / z 421$

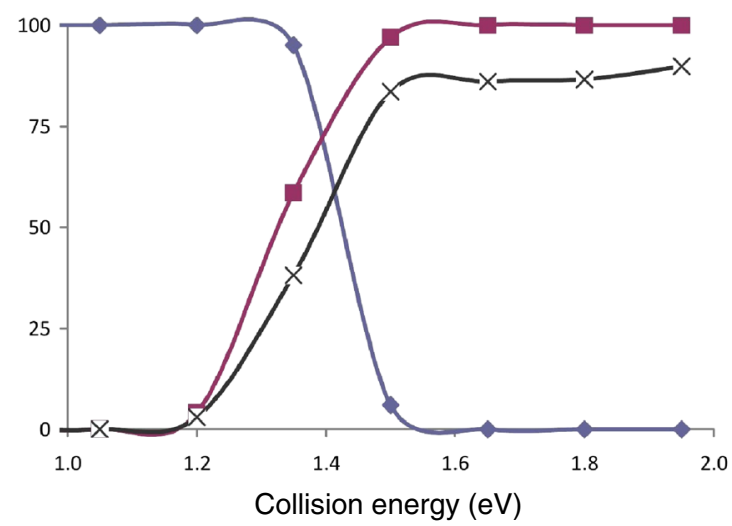

$\rightarrow$ precursor ion $(\mathrm{m} / \mathrm{z} 549)$

$-\mathrm{m} / \mathrm{z} 513$

$-x-m / 2421$

(d)

Figure 3. Energy-resolved mass spectrometry diagrams obtained by selecting the species $\left[\mathrm{AOTM}^{\prime \prime} \mathrm{Cl}_{2}\right]^{-}$as precursor ion. From top to bottom: $\mathrm{M}^{\prime \prime}=\mathrm{Mg}$ (a), $\mathrm{Ca}(\mathrm{b}), \mathrm{Mn}(\mathrm{c}), \mathrm{Ni}(\mathrm{d})$.

monomeric species $\left[\mathrm{AOTM}^{\prime \prime} \mathrm{Cl}_{2}\right]^{-}$have been studied and characterized by electrospray mass spectrometry, CID multiple-stage mass spectrometry, energy-resolved mass spectrometry and theoretical calculations. Their main decomposition pathways consist in consecutive losses of $\mathrm{HCl}, \mathrm{C}_{8} \mathrm{H}_{16} \mathrm{O}$, and the radical - $\mathrm{C}_{8} \mathrm{H}_{17}$. It is worth to note that none of the AOT-alkaline metal ion aggregates, both as cationic and anionic species, characterized until now, showed the loss of a radical alkyl chain. Further, no radical formation has been found in cationic AOT-divalent metal ion aggregates recently characterized by us. So the presence of a divalent metal ion, together with an overall negative charge, seems to be crucial for activating an unusual decomposition pathway consisting in a loss of a radical from the even-electron anions [AOTM" $\left.\mathrm{Cl}_{2}-\mathrm{HCl}-\mathrm{C}_{8} \mathrm{H}_{18} \mathrm{O}\right]^{-}$.

Other decomposition pathways involve elimination of $\mathrm{M}^{\prime \prime} \mathrm{Cl}_{2}$ from $\left[\mathrm{AOTM} \mathrm{Cl}_{2}\right]^{-}$or the formation of $\left[\mathrm{HSO}_{3} \mathrm{M}^{\prime \prime} \mathrm{Cl}_{2}\right]^{-}$. A different 


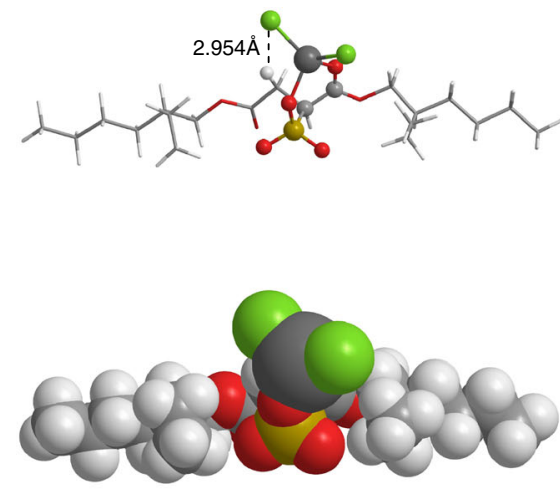

1a
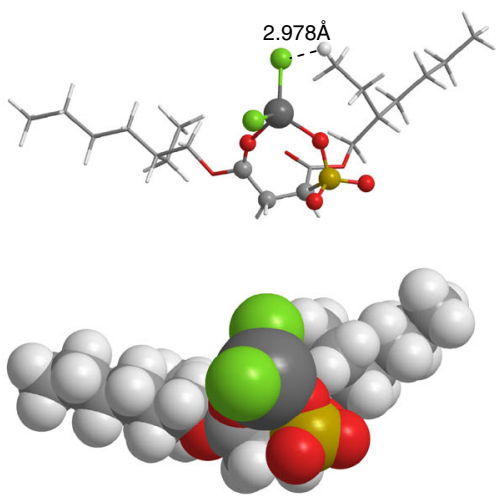

1b

Figure 4. Two views of the two most stable energy minimized structures of the anionic monomer $\left[A O T M g C l_{2}\right]^{-}$at the $B 3 L Y P / 6-311+G(d, p)$ level: the most stable structure (1a) and a structure differing $+4.09 \mathrm{kcal} \mathrm{mol}^{-1}(\mathbf{1} \mathbf{b})$. The most significant $\mathrm{Cl}$. . $\mathrm{H}$ interactions are given (distances are in $\AA$ ).

\begin{tabular}{|c|c|c|c|c|c|}
\hline Structure & B3LYP $6-311+G(d, p)^{a}$ & ZPVE $^{\mathrm{b}}$ & $\mathrm{SCF}+\mathrm{ZPVE}^{\mathrm{a}}$ & $\Delta \mathrm{E}(\mathrm{SCF}+\mathrm{ZPVE})^{\mathrm{c}}$ & $\left\langle\mathrm{S}^{2}\right\rangle$ \\
\hline \multicolumn{6}{|c|}{$\left[\mathrm{AOTMgCl}_{2}\right]^{-}$} \\
\hline $1 \mathrm{a}$ & -2830.472144 & 0.564847 & -2829.907297 & 0 & \\
\hline $1 \mathrm{~b}$ & -2830.466039 & 0.565262 & -2829.900777 & +4.09 & \\
\hline $1 \mathrm{c}$ & -2830.452633 & 0.565085 & -2829.887548 & +12.39 & \\
\hline \multicolumn{6}{|c|}{$[\mathrm{AOTMgCl}-\mathrm{HCl}]^{-}$} \\
\hline $2 a$ & -2369.575190 & 0.551286 & -2369.023904 & 0 & \\
\hline $2 \mathbf{b}$ & -2369.562617 & 0.553749 & -2368.993462 & +9.43 & \\
\hline $2 c$ & -2369.543651 & 0.550189 & -2368.993462 & +19.10 & \\
\hline \multicolumn{6}{|c|}{ [AOTMgCl$\left._{2}-\mathrm{HCl}-\mathrm{C}_{8} \mathrm{H}_{18} \mathrm{O}\right]^{-}$} \\
\hline $3 a$ & -1978.473618 & 0.297447 & -1978.1761715 & 0 & \\
\hline $3 \mathbf{b}$ & -1978.471583 & 0.296232 & -1978.175351 & +0.52 & \\
\hline $3 c$ & -1978.455536 & 0.297761 & -1978.157775 & +11.54 & \\
\hline \multicolumn{6}{|c|}{$\left[\mathrm{C}_{4} \mathrm{HO}_{6} \mathrm{SMgCl}^{-\bullet}\right.$} \\
\hline $4 a$ & -1663.317746 & 0.060657 & -1663.257089 & 0 & 0.75 \\
\hline $4 b$ & -1663.263453 & 0.057857 & -1663.205596 & +32.31 & 0.76 \\
\hline $4 c$ & -1663.262028 & 0.057853 & -1663.204175 & +33.20 & 0.76 \\
\hline
\end{tabular}

behavior is shown by $\left[\mathrm{AOTNil}{ }^{\prime \prime} \mathrm{Cl}_{2}\right]^{-}$for which eliminations of AOT side chain are undetectable.

Theoretical calculations have allowed to optimize the structure of different negatively charged species, to gain useful information on the main sites of binding of AOT with metal ion, on the resulting AOT folding and to prove some insight into the species involved in the decomposition reactions of $[\mathrm{AOTMgCl}]^{-}$.

These findings add significant information to the gas phase chemistry of surfactants, and AOT in particular, to its intrinsic bonding properties with divalent metal ions and on sites involved, independently by the influence of the solvent, packing, reticular, and other intermolecular forces. The evaluation of the role exerted by metal ions and halide counter ions, as well as by the overall charge of the aggregate has been carried out. This information can be of value also in condensed phase chemistry of AOTalkaline metal ion aggregates.

Finally, the loss of a radical, that is, ${ }^{\circ} \mathrm{C}_{8} \mathrm{H}_{17}$, occurring in the decomposition pathways of the even-electron $\left[\mathrm{AOTM}^{\prime \prime} \mathrm{Cl}_{2}\right]^{-}$anion, never observed neither for AOT-alkaline metal ion aggregates, both as cationic and anionic species, nor for AOT-divalent metal ion positively charged aggregates, represents a further example of 'unusual' decomposition of even-electron species and a further exception to the 'even-electron rule'. 

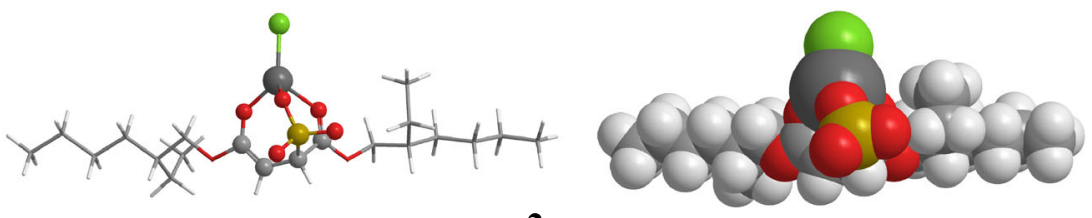

$2 \mathbf{a}$

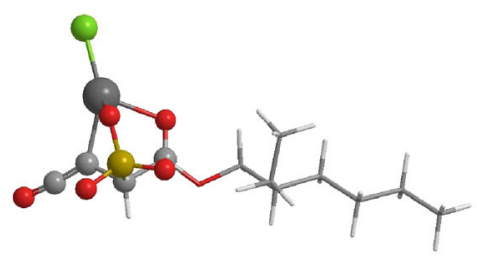

3a
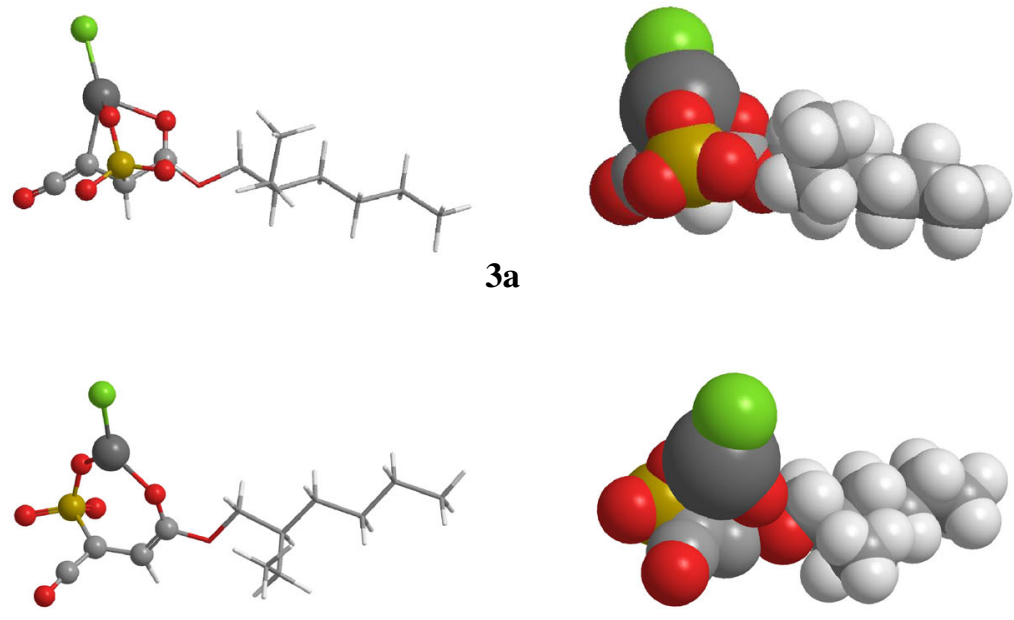

$\mathbf{3 b}$
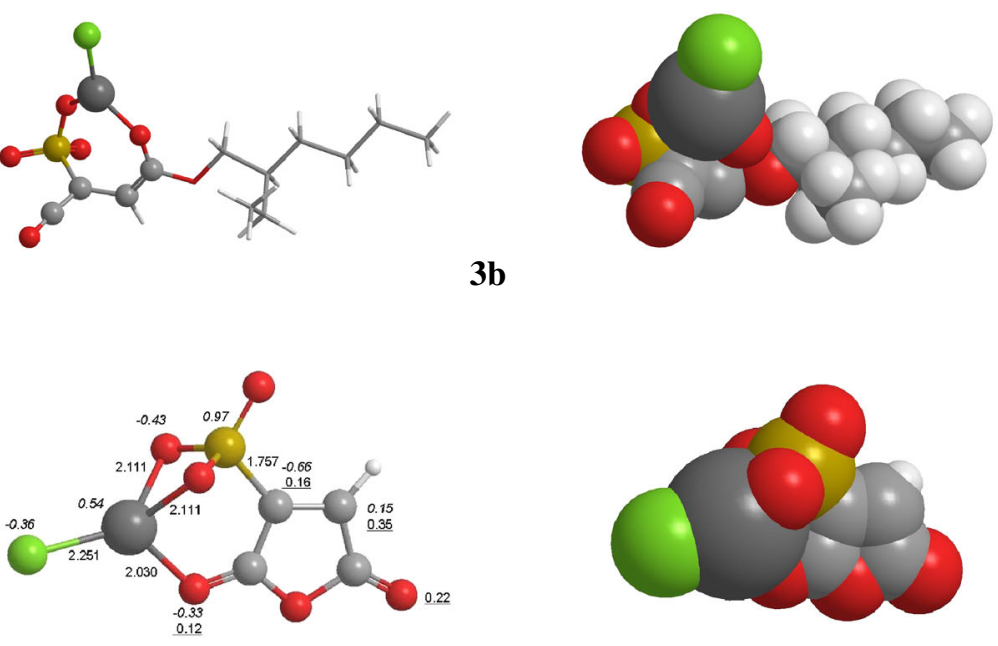

$4 \mathbf{a}$

Figure 5. Two views of the most stable energy minimized structures of $\left[\mathrm{AOTMgCl}_{2}-\mathrm{HCl}\right]^{-}(\mathbf{2 a}),\left[\mathrm{AOTMgCl}_{2}-\mathrm{HCl}_{-} \mathrm{C}_{8} \mathrm{H}_{16} \mathrm{O}\right]^{-}(\mathbf{3 a}, \mathbf{3} \mathbf{b})$ and the radical anion $\left[\mathrm{C}_{4} \mathrm{HO}_{6} \mathrm{SMgCl}^{-\bullet}(\mathbf{4 a})\right.$. Significant charge density (italics), spin density (underlined), and bond distances $(\AA)$ are reported for $4 \mathbf{4 a}$.

\section{References}

[1] J. N. Israelachvili, D. J. Mitchell, B. W. Ninhmam. Theory of self-assembly of hydrocarbon amphiphiles into micelles abd bilayers. J. Chem. Soc. Faraday Trans 2 1976, 72, 1525-1568.

[2] V. Turco Liveri. Nanosurface Chemistry, M Rosoff (Ed). Marcel Dekker: New York, 2002, 473

[3] H. A. Gazzaz, B. H. Robinson. Kinetics involving divalent metal ions and ligands in surfactant self-assembly systems: applications to metal-ion extraction. Langmuir 2000, 16, 8685-8691.

[4] P. C. Griffiths, I. A. Fallis, T. Chuenpratoom, R. Watanesk. Metallosurfactants: interfaces and micelles. Adv. Colloid Interface Sci. 2006, 122, 107-117.

[5] D. J. Tobias, M. L. Klein. Molecular dynamics simulations of a calcium carbonate/calcium sulfonate reverse micelle. J. Phys. Chem. 1996, $100,6637-6648$

[6] L. Ceraulo, G. Giorgi, V. Turco Liveri, D. Bongiorno, S. Indelicato, F. Di Gaudio, S. Indelicato. Mass spectrometry of surfactant aggregates. Eur. J. Mass Spectrom. 2011, 17, 525-541.

[7] I. Lisiecki, M. P. Pileni. Synthesis of well-defined and low size distribution cobalt nanocrystals: the limited influence of reverse micelles. Langmuir 2003, 19, 9486-9489.

[8] M. P. Pileni. Mesostructured fluids in oil-rich regions: structural and templating approaches. Langmuir 2001, 17, 7476-7486.

[9] P. Andre, B. W. Ninham, M. P. Pileni. Supra-aggregates. Adv. Colloid Interface Sci. 2001, 89-90, 155-167.

[10] D. Ingert, L. Motte, M. P. Pileni. Surfactant science series. In Fine Particles. Marcel Dekker, Inc, 2000, 217-234.
[11] M. Andersson, I. Harelind, P. Hanna, E. C. Anders, M. Skoglundh, K. Holmberg. Self-Assembly. R. H. Brian (Ed). IOS Press: Amsterdam, 2003.

[12] A. Filankembo, P. André, I. Lisiecki, C. Petit, T. Gulik-Krzywicki, B. W. Ninham, M. P. Pileni. Mesostructured fluids: supra aggregates made of interdigitated reverse micelles. Colloids Surf. A Physicochem. Eng. Asp. 2000, 174, 221-232.

[13] E. Bardez, N. C. Vy, Th. Zemb. Counter-ion driven sphere to cylinder transition in reverse micelles: a small angle $\mathrm{x}$-ray scattering and conductimetric study. Langmuir 1995, 11, 3374-3381.

[14] E. Bardez, B. Larrey, X. X. Zhu, B. Valeur. Counterion control of reactivity in anionic reverse micellar aggregates. Chem. Phys. Lett. 1990, 171, 362-368.

[15] X. X. Zhu, E. Bardez, L. Dallery, B. Larrey, B. Valeur. Counterion effect on the properties of water encased in anionic reverse micellar aggregates. An investigation by ${ }^{1} \mathrm{H}$ NMR. New J. Chem. 1992, 16, 973-977.

[16] F. Aliotta, P. Migliardo, D. I. Donato, V. Turco Liveri, E. Bardez, B. Larrey. Local hydration effects in reversed micellar aggregates. Prog. Colloid Polym. Sci. 1992, 89, 258-262.

[17] R. Giordano, P. Migliardo, U. Wanderlingh, E. Bardez, C. Vasi. Structural properties of micellar solutions. J. Mol. Struct. 1993, 296, 265-269.

[18] S. C. Wang, H. Yang, S. Banerjee I. P. Herman, D. L. Akins. AOT dispersed single-walled carbon nanotubes for transistor device application. Mater. Lett. 2008, 62, 843-845.

[19] D. Ingert, M. P. Pileni. Limitations in producing nanocrystals using reverse micelles as nanoreactors. Adv. Funct. Mater. 2001, 11, 136-139. 
[20] M. P. Pileni. Nanosized particles made in colloidal assemblies. Langmuir 1997, 13, 3266-3276.

[21] G. Giorgi, L. Ceraulo, V. Turco Liveri. Surfactant self-assembly in the gas phase: bis(2-ethylhexyl)sulfosuccinate-alkaline metal. J. Phys. Chem. B 2008, 112, 1376-1382.

[22] G. Giorgi, E. Giocaliere, L. Ceraulo, A. Ruggirello, V. Turco Liveri. Spatially ordered surfactant assemblies in gas phase: negatively charged bis(2-ethylhexyl)-sulfosuccinate-alkaline metal ion aggregates. Rapid Commun. Mass Spectrom. 2009, 23, 2206-2212.

[23] G. Giorgi, I. Pini, L. Ceraulo, A. Ruggirello, V. Turco Liveri. Gas phase charged aggregates of bis(2-ethylhexyl)sulfosuccinate (AOT) and divalent metal ions. first evidence of AOT solvated aggregates. $J$. Mass Spectrom. 2011, 46, 925-932.

[24] Y. Fang, A. Bennett, J. Liu. Multiply charged gas-phase NaAOT reverse micelles: formation, encapsulation of glycine, and collisioninduced dissociation. Int. J. Mass Spectrom. 2010, 293, 12-22.

[25] D. Bongiorno, L. Ceraulo, G. Giorgi, S. Indelicato, A. Ruggirello, V. Turco Liveri. Supramolecular aggregates in vacuum: positively monocharged sodium alkanesulfonate clusters. Eur. J. Mass Spectrom. 2010, 16, 151-161.

[26] D. Bongiorno, L. Ceraulo, G. Giorgi, S. Indelicato, M. Ferrugia, A. Ruggirello, V. Turco Liveri. Effects of the extracharge polarity on abundance and stability of supramolecular surfactant aggregates in gas phase. J. Mass Spectrom. 2011, 46, 195-201.

[27] M. J. Frisch, G. W. Trucks, H. B. Schlegel, G. E. Scuseria, M. A. Robb, J. R. Cheeseman, G. Scalmani, V. Barone, B. Mennucci,
G. A. Petersson, H. Nakatsuji, M. Caricato, X. Li, H. P. Hratchian, A. F. Izmaylov, J. Bloino, G. Zheng, J. L. Sonnenberg, M. Hada, M. Ehara, K. Toyota, R. Fukuda, J. Hasegawa, M. Ishida, T. Nakajima, Y. Honda, O. Kitao, H. Nakai, T. Vreven, J. A. Montgomery, Jr., J. E. Peralta, F. Ogliaro, M. Bearpark, J. J. Heyd, E. Brothers, K. N. Kudin, V. N. Staroverov, T. Keith, R. Kobayashi, J. Normand, K. Raghavachari, A. Rendell, J. C. Burant, S. S. lyengar, J. Tomasi, M. Cossi, N. Rega, J. M. Millam, M. Klene, J. E. Knox, J. B. Cross, V. Bakken, C. Adamo, J. Jaramillo, R. Gomperts, R. E. Stratmann, O. Yazyev, A. J. Austin, R. Cammi, C. Pomelli, J. W. Ochterski, R. L. Martin, K. Morokuma, V. G. Zakrzewski, G. A. Voth, P. Salvador, J. J. Dannenberg, S. Dapprich, A. D. Daniels, O. Farkas, J. B. Foresman, J. V. Ortiz, J. Cioslowski, D. J. Fox. Gaussian 09, Revision B.01. Gaussian, Inc.: Wallingford CT, 2010.

[28] A. D. Becke. Density-functional thermochemistry. III. The role of exact exchange. J. Chem. Phys. 1993, 98, 5648-5652.

[29] Y. Cai, Z. Mo, N. S. Rannulu, B. Guan, S. Kannupal, B. C. Gibb, R. B. Cole. Characterization of an exception to the 'even-electron rule' upon low-energy collision induced decomposition in negative ion electrospray tandem mass spectrometry. J. Mass Spectrom. 2010, 45, 235-240, and references cited therein.

[30] R. G. Cooks, J. H. Beynon, R. M. Caprioli, G. R. Lester. Metastable lons. Elsevier: Amsterdam, 1973.

[31] A. M. Boulanger, E. E. Rennie, D. M. P. Holland, D. A. Shaw, P. M. Mayer. Entropy effects in the fragmentation of 1,1-dimethylhydrazine ions. J. Phys. Chem. A 2007, 111, 5388-5398. 